\title{
UNGKAPAN METAFORIS BAHASA MELAYU TERNATE DI DESA SEA TUMPENGAN, SEA MITRA, DAN BUHA METAPHORICAL EXPRESSIONS OF TERNATE MALAY IN SEA TUMPENGAN VILLAGE, SEA MITRA VILLAGE, AND BUHA VILLAGE
}

\author{
Vivi Nansy Tumuju \\ Fakultas Ilmu Budaya Unsrat Manado \\ Jalan Kampus Unsrat Bahu, Manado, Sulawesi Utara \\ vntumuju@yahoo.com
}

\begin{abstract}
The application of metaphorical expression malay ternate became daily expressions in the society. Expressions delivered are attempts to unite the cultural diversity of ternate with other residents.

the users of malay ternate of ternate sub-ethnic who lived in the sea tumpengan village, sea mitra, and buha, contain many metaphorical expressions. the meanings of metaphorical expressions show the kinship and mindset of society of the ternate malay language speakers.

it was found that metaphorical expression and the meaning contained in it is summed up in a few metaphorical expressions that have elements of reprimands, warnings, and advice. ternate malay language is rich with metaphorical expressions that have meaning manners, advice, ethics, religious norms, and legal norms. examples of metaphorical expression meaning reprimand delivered spontaneously in speaking to someone who does not have a permanent job or a lazy person. meaning of warning is a statement to anyone else who would do an activity and the person who will deliver the metaphorical expression already know the impact it will have. advice is delivered to the other party because of something that already does not look normal or have already exceeded the capacity that would be bad.
\end{abstract}

Keywords: metaphorical expression, meaning, mindset

\begin{abstract}
Abstrak
Penerapan ungkapan metaforis bahasa Melayu Ternate menjadi ungkapan sehari-hari dalam masyarakat. Ungkapan-ungkapan yang terjadi merupakan upaya untuk mempersatukan keanekaragaman budaya orang Ternate dengan penduduk lainnya.

Pengguna bahasa Melayu Ternate pada subetnik Ternate yang sudah menetap di desa Sea Tumpengan, Sea Mitra, dan Buha banyak mengandung ungkapan-ungkapan metaforis. Makna ungkapan metaforis menunjukkan ciri khas hubungan kekerabatan dan pola pikir mayarakat penutur bahasa Melayu Ternate tersebut. Ungkapan metaforis dan makna yang terkandung di dalamnya yang ditemukan dalam beberapa ungkapan metaforis memiliki unsur teguran, peringatan, dan nasihat. Bahasa Melayu Ternate kaya dengan ungkapan metaforis yang memiliki makna sopan santun, nasihat, etika, norma agama, dan norma hukum. Contoh ungkapan metaforis yang memiliki makna teguran disampaikan secara spontan dalam bertutur kepada seseorang yang tidak memiliki pekerjaan tetap atau orang malas. Makna peringatan merupakan suatu pernyataan kepada pihak lain yang akan melakukan suatu aktivitas dan orang yang akan menyampaikan ungkapan metaforis tersebut sudah mengetahui dampak yang akan terjadi. Nasihat disampaikan kepada pihak lain karena adanya sesuatu yang sudah tidak kelihatan normal atau sudah melebihi kapasitas yang akan berakibat buruk.
\end{abstract}

Kata kunci: Ungkapan metaforis, makna, pola pikir

\section{Pendahuluan}

\subsection{Latar Belakang Pemikiran}

Bahasa merupakan salah satu media utama yang digunakan manusia untuk berkomunikasi, baik lisan maupun tulis. Bahasa adalah salah satu unsur kebudayaan manusia yang dapat mencerminkan kebudayaan masyarakat penuturnya. Bahasa dipandang sebagai salah satu sarana terpenting bagi manusia dalam kehidupan sosial budaya dan tidak terlepas 
dari unsur-unsur kebudayaan lain yang saling mempengaruhi satu dengan yang lainnya (Koentjaraningrat, 1990:160).

Alat komunikasi penutur subetnis Ternate adalah bahasa Melayu Ternate. Penutur bahasa Melayu Ternate meliputi Provinsi Maluku Utara (Halmahera). Bahasa Melayu Ambon meliputi Maluku Barat. Kedua provinsi ini memiliki bahasa setempat yang lebih dikenal sebagai bahasa-bahasa Indonesia Timur. Menurut Dyen (1984), bahasa-bahasa Indonesia Timur, antara lain 1. rumpun Ambon Timur, rumpun Sula-Bacan, rumpun Halmahera Selatan, dan Papua bagian barat; 2. Bahasa Halmahera Utara, rumpun Timur Laut: Loda, Tobelo, Tabaru; rumpun Tengah: Kau, Isan; rumpun Barat: Waioli, Madok, Galela, Ibu; rumpun Selatan: Ternate, Tidore.

Secara spesifik penutur asli bahasa daerah Ternate yang juga setiap hari dapat menggunakan bahasa Melayu Ternate dengan aktif adalah masyarakat yang ada di desadesa, antara lain di Kampung Makasar, Soa Sio, Salero, Kastuarian, Tobeleu, Ake Bo'oca, Sabia, Sangaji, Gam Cim, Toloko, Dufa-Dufa, Tubo, Akehuda, Tafure, Tabam, Sango, Tarau, Kulaba, Akeruru, Tabanga, Tobololo, dan Sasa. Berdasarkan tinjauan geografis, bahasa Melayu Ternate digunakan oleh hampir seluruh masyarakat Ternate. Bagi orang Ternate, bahasa Melayu Ternate merupakan salah satu cerminan identitas diri, untuk dikenal sebagai masyarakat asli Ternate. Pulau Ternate adalah sebuah pulau yang terdiri dari kota Ternate sebagai ibu kota Provinsi Maluku Utara dan desa-desa di sekitarnya.

Dalam Studi Linguistik Umum yang dilakukan oleh Parera (1987:13), dikatakan bahwa bahasa merupakan suatu objek yang dapat ditelaah secara ilmiah. Berdasarkan konteks ini, peneliti menelaah bahasa Melayu Ternate (BMT) sebagai objek bahasa secara umum untuk menganalisis pola pikir di balik ungkapan metaforisnya. Penelitian ini lebih menekankan pada makna kebahasaannya (linguistik) tanpa mengesampingkan ruang lingkup masyarakat penutur bahasa tersebut.

Dalam komunikasi sehari-hari BMT yang digunakan oleh subetnis Ternate yang sudah menetap di Kota Manado, khususnya di desa Sea Tumpengan, Sea Mitra, dan Buha banyak terdapat ungkapan-ungkapan metaforis. Makna ungkapan metaforis BMT menunjukkan ciri khas dari suatu hubungan kekerabatan untuk mengetahui pola-pikir masyarakat penutur BMT tersebut.

Penelitian ini mencoba menjelaskan bagian ungkapan metaforis BMT yang mengandung makna negatif dan makna positif yang bertujuan untuk mengidentifikasi dan menganalisis ungkapan-ungkapan metaforis BMT serta menjelaskan pola pikir di balik ungkapanungkapan tersebut.

Folley (1997:191) mengatakan bahwa metafora adalah sebuah pernyataan yang menafsirkan serta menjelaskan hal lain, seringkali pernyataan itu sedikit mendekati, suatu hal menggantikan serta menjelaskan sifat-sifat lain yang hampir sama dengan suatu hal yang dimaksudkan. Selanjutnya, Saussure (1966) mengatakan bahasa adalah suatu sistem tanda yang mengungkapkan gagasan. Oleh karena itu, sistem tanda dapat digunakan pada sistem upacara-upacara simbolis, ekspresi sopan santun, dan lain-lain. Bahasa secara utuh berupa serangkaian impresi yang tersimpan dalam benak masyarakat. Menurut Peirce (2006:227) tanda menunjukkan suatu fakta 
kepada penafsirannya. Oleh karena itu, suatu tanda tidak pernah berupa suatu entitas yang sendirian, tetapi yang memiliki ketiga aspek tersebut. Tanda juga membangkitkan semiotika yang tak terbatas, selama suatu penafsir yang membaca tanda sebagai tanda bagi yang lain, yaitu sebagai wakil dari suatu makna atau penanda, bisa ditangkap oleh penafsir lainnya. Tafsiran makna inilah yang akan dikembangkan dalam penelitian ini.

\subsection{Rumusan Masalah}

Berdasarkan latar belakang di atas yang menjadi permasalahan penelitian ini dapat dirumuskan sebagai berikut.

1. Apa saja ungkapan metaforis yang ada dalam BMT di lingkungan masyarakat Ternate di Sea Tumpengan, Sea Mitra, dan Buha?

2. Apa makna ungkapan-ungkapan tersebut?

3. Bagaimana ungkapan-ungkapan itu mencerminkan pola pikir penutur BMT?

\subsection{Tujuan Penelitian}

Penelitian ini bertujuan untuk:

1. mengidentifikasi ungkapan-ungkapan metaforis BMT di lingkungan masyarakat Ternate di Sea Tumpengan, Sea Mitra, dan Buha.

2. menganalisis makna di balik ungkapanungkapan tersebut.

3. menjelaskan pola pikir yang ada di balik ungkapan metaforis BMT.

\subsection{Manfaat Penelitian}

Dari hasil penelitian ini dapat diperoleh dua manfaat, yaitu manfaat teoretis dan manfaat praktis.

\subsubsection{Manfaat Teoretis}

Hasil penelitian ini diharapkan dapat memberikan masukan dan manfaat bagi perkembangan ilmu linguistik, khususnya dalam bidang linguistik antropologi, terutama kajian tentang pola pikir yang ada pada ungkapan metaforis BMT.

\subsubsection{Manfaat Praktis}

Hasil penelitian ini memberikan sumbangan pemikiran bagi pembaca untuk mengenal serta memahamiungkapan-ungkapanmetaforisdalam BMT dan mengetahui pola pikir yang bermakna budaya di balik ungkapan-ungkapan BMT. Manfaat praktis lain, secara umum penelitian ini menambah referensi di bidang bahasa. Secara khusus, bagi masyarakat etnis Ternate penelitian ini bermanfaat sebagai penemuan di bidang ilmu pengetahuan yang merupakan keunikan etnis mereka, dan merupakan kekayaan budaya daerah sebagai aset nasional.

\section{Tinjauan Pustaka dan Kerangka Teori}

\subsection{Tinjauan Pustaka}

Penelitian tentang bahasa dan etnis Ternate sudah pernah dilakukan oleh peneliti-peneliti di bidang bahasa dan peneliti-peneliti di bidang antropologi. Beberapa referensi penelitian tentang etnis Ternate dan menjadi bahan pustaka, antara lain Sejarah dan Perkembangan Melayu Ternate (Apituley, 1983). Dari hasil laporan penelitian di Maluku Utara yang dilakukan Departemen Pendidikan dan Kebudayaan Jakarta, diungkapkan bahwa bahasa Maluku merupakan induk dari berbagai bahasa Melayu yang ada di Maluku Utara, (Apituley, 1983:34). Selanjutnya, Syapora (2008:7 \& 98) dalam hipotesisnya "Meretas Bahasa Daerah di Bawah Garis Katulistiwa" dibicarakan bahwa anak-anak di Gruapin Kayoa hampir sebagian besar sudah tidak menggunakan bahasa Kayoa, tetapi lebih akrab menggunakan bahasa Melayu 
Ternate. Muhamad (2007) dalam penelitiannya yang berjudul "Makna Budaya Ungkapan dalam Tarian Tradisional Togal di Makian Pulau (Makian Dalam) Kabupaten Halmahera Selatan", dibicarakan tentang ungkapanungkapan yang ada dalam tarian Togal merupakan ungkapan dalam bentuk pantun singkat yang dilagukan. Ungkapan-ungkapan tersebut terdiri dari ungkapan percintaan dan nasihat. Dari keseluruhan ungkapan dalam tarian tradisional Togal tersirat makna budaya yang mencerminkan pola pikir masyarakat etnik Makian. Pulau Makian merupakan salah satu di antara pulau-pulau yang terdapat di Maluku Utara. Selanjutnya, Sangaji (1991) melaksanakan penelitian tentang kata sapaan dan sistemnya dalam bahasa Makian. Menurutnya, bahasa Makian berasal dari daratan Halmahera dan sekitarnya.

Selanjutnya, berikut ini beberapa penelitian tentang bahasa-bahasa di daerah Maluku Utara dan sekitarnya, Campen CFH (1885) dengan judul penelitian Ternataansche pantoen's; Grimes and Grimes (1984) dalam makalah pada seminar Maluku dan Irian Jaya tentang Bahasabahasa Daerah di Maluku Utara dan Halmahera Tengah; Heuting (1907) dalam penelitiannya Lets over de "Ternataansch-Halmaherasche" taal groep. Pada tahun 1973 Abdurachman, Paramita R. et al. melaksanakan penelitian dengan judul Bunga Rampai Sejarah Maluku. Nendisse (1991) membahas masyarakat di pulau Ambon dan kepulauan Lease yang berbahasa daerah Ambon dan di pulau Ternate mengenal pula tradisi lisan dalam bentuk ungkapan-ungkapan. Ungkapanungkapan itu semua diucapkan secara spontan. Makna yang terkandung di dalamnya ada yang diungkapkan secara terselubung, misalnya dengan arti kiasan atau metafora, tetapi ada juga yang diungkapkan secara wajar.

Dari penulisan-penulisan ilmiah berupa bahan-bahan referensi yang ada tentang bahasa Melayu Ternate, khususnya meneliti pola pikir di balik ungkapan metaforis BMT (dikaji dari perspektif linguistik antropologi) belum ada. Oleh karena itu, perlu diadakan penelitian tentang itu.

\subsection{Kerangka Teori}

Penelitian ini mengkaji pola pikir di balik ungkapan metaforis BMT yang berupa sebuah kajian dari perspektif linguistik antropologi. Dalam kajian budaya, Koentjaraningrat (1965:89) mengemukakan bahwa dari segi antropologi budaya hampir semua manusia di dunia, hidup individu dibagi oleh adaptasi masyarakat dalam tingkat-tingkat tertentu yang disebut stages of long life-cycle atau tingkat-tingkat sepanjang hidup individu.

Masinambouw (1998:14) mengatakan bahwa kebudayaan merupakan suatu keseluruhan yang kompleks, menyangkut semua yang dapat kita amati pada manusia sebagai makhluk sosial dan dengan sendirinya termasuk bahasa di dalamnya. Bahasa menununjukkan pikiran seseorang dan dalam pikiran itu dapat diketahui melalui penggunaan bahasanya. Marvin Harris (dalam Spradley, 1979) mengatakan bahwa kebudayaan ditampakkan dalam pola tingkah laku dan dikaitkan dengan pola pikir masyarakat tertentu, seperti adat dan kebiasaan masyarakat.

Menurut hipotesis Casson (1981), bahasa mempunyai hubungan erat dengan kebudayaan. Dalam hubungan ini, kebudayaan ditentukan oleh bahasa karena bahasa memberikan petunjuk untuk pemahaman makna-makna budaya yang mencakup berbagai aspek kebudayaan. Ada ungkapan-ungkapan yang memperlihatkan ketergantungan masyarakat 
kepada alam atau lingkungan. Jadi, bahasa mencerminkan budaya. Selanjutnya, asumsi yang menjadi pokok pemikiran, yaitu perilaku pada masyarakat ditentukan, antara lain oleh pandangan mengenai kenyataan dan kenyataan itu ditentukan oleh bahasa. Dengan perkataan lain, jalan pikiran manusia cenderung terbentuk oleh bahasa yang digunakan.

Metafora adalah bahasa kiasan dan di bawah ini adalah pemaparan tentang bahasa kiasan. Menurut Ross (2006) bahasa kiasan adalah deviasi pemikiran atau ekspresi dari metode ucapan asli dan sederhana atau suatu kiasan yang secara seni berbeda dari penggunaan umum. Kiasan-kiasan ini disebut oleh orang Yunani 'schema' dan orang Romawi 'figura'. Kedua kata tersebut berarti shape atau figure. Suatu skema meliputi suatu deviasi dari pola asli atau pengaturan kata, sedangkan suatu trope meliputi deviasi dari aslinya dan arti penting sebuah kata. Ia juga menjelaskan makna bahasa kiasan dengan mengutip kata-kata dari Aquinas sebagai berikut: "Melalui kata-kata sesuatu ditunjukkan secara nyata dan kiasan. Bukan kiasan itu sendiri, tetapi yang dikiaskan, arti literalnya. Saat Alkitab mengatakan 'tangan Tuhan', arti literalnya bukan Tuhan memiliki anggota tubuh seperti itu, tetapi arti yang ditunjukkan oleh anggota tubuh itu, yaitu 'kuasa yang bekerja"'.

Gaya bahasa kiasan (metaforis) diterangkan secara panjang lebar oleh Keraf (2002: 136137) dalam bukunya Diksi dan Gaya Bahasa. Di dalam buku tersebut diterangkan bahwa gaya bahasa kiasan ini pertama-tama dibentuk berdasarkan perbandingan atau persamaan. Membandingkan sesuatu dengan sesuatu yang lain, berarti mencoba menemukan ciri-ciri yang menunjukkan kesamaan antara kedua hal tersebut.Perbandingansebenarnyamengandung dua pengertian, yaitu perbandingan yang termasuk gaya bahasa yang polos atau langsung dan perbandingan yang termasuk gaya bahasa kiasan.

Dalam menetapkan apakah suatu perbandingan itu merupakan bahasa kiasan atau tidak hendaknya diperhatikan tiga hal, yaitu (1) tetapkanlah terlebih dahulu kelas kedua hal yang diperbandingkan, (2) perhatikan tingkat kesamaan atau perbedaan antara kedua hal tersebut, (3) perhatikan konteks dari ciri-ciri kedua hal itu. Jika tidak ada kesamaan, maka perbandingan itu bahasa kiasan.

Dalam Longman (2005) Active Students 'Dictionary, metafora adalah 'way of describing something by comparing it to something else that has similar qualities, without using the words 'like' or 'as' (cara menggambarkan sesuatu dengan membandingkannya dengan sesuatu yang lain dengan memiliki kualitas yang sama, tanpa menggunakan kata-kata 'seperti' atau 'bagaikan'). Definisi metafora ini juga searah dengan definisi yang diberikan oleh Sudjiman (1983: 4), "Metafora sebagai bahasa kiasan yang mengandung perbandingan yang tersirat sebagai pengganti kata atau ungkapan lain untuk melukiskan kesamaan atau kesejajaran makna."

Siregar (2004) menyatakan bahwa metafora menayangkan peta kognitif dari satu ranah sumber (yaitu wahana) kepada satu ranah sasaran (tenor) sehingga menyebabkan sasaran menjadi terikat dalam pengalaman fisik spasial melalui ranah sumber. Hasilnya, skema-skema yang mempengaruhi di antara tingkat konseptual dan inderawi dalam ranah sumber menjadi aktif, begitu juga dalam ranah sasaran. Dalam pandangan ini satu skema metaforis merupakan satu representasi mental yang mengikat struktur konseptual (intelektual) dari satu ranah abstrak 
ke dalam basis ranah inderawi (fisikal) lain yang lebih fisikal.

Jakobson (1979) dalam teori sastra masa kini menyarankan bahwa tingkah laku tuturan juga cenderung kepada salah satu ekstrim, sedangkan gaya sastra mengekspresikan dirinya sendiri sebagai sebuah sandaran terhadap metafora. Perkembangan sejarah dari romantisme, realisme, sampai kepada simbolisme dapat dimengerti sebagai pergantian gaya dari metafora ke matonimi dan kembali lagi ke matafora.

Siregar (PELBA 17, 2004:139) melihat metafora sebagai tambahan dekoratif untuk memperindah bahasa sehari-hari. Menurutnya, metafora merupakan bagian dari bahasa figuratif karena metafora diartikan sebagai kata yang tidak menggunakan makna sehari-hari. Bahasa sehari-hari tidak memiliki metafora yang menggunakan cara-cara di luar ranah bahasa sehari-hari.

Untuk menafsirkan makna ungkapan metaforis akan digunakan teori semiotika de Saussuredan Peirce.Saussure (1966) mengatakan bahwa bahasa adalah suatu sistem tanda yang mengungkapkan gagasan. Oleh karena itu, sistem tanda yang digunakan dapat digunakan dengan sistem alfabet bisu tuli, upacara-upacara simbolis, ekspresi sopan santun, sinyal-sinyal militer, dan lain-lain. Bahasa secara utuh, berupa serangkaian impresi yang tersimpan dalam benak setiap anggota masyarakat. Dikatakannya juga bahwa tanda adalah kesatuan dari suatu bentuk penanda dengan sebuah ide atau petanda. Dengan kata lain, penanda adalah bunyi yang bermakna atau coretan yang bermakna. Jadi, penanda adalah aspek material dari bahasa: apa yang dikatakan atau didengar dan apa yang ditulis atau dibaca. Petanda adalah gambaran mental, pikiran, atau konsep. Selanjutnya,
Peirce (2006:227) mengatakan bahwa tanda itu sendiri merupakan penafsirannya -unsur pengantara- adalah contoh dari keketigaan. Ia berusaha untuk menemukan struktur terner di mana pun mereka bisa terjadi. Keketigaan yang ada dalam konteks pembentukan tanda juga membangkitkan semiotika yang tak terbatas, selama suatu penafsir (gagasan) yang membaca tanda sebagai tanda bagi yang lain (yaitu sebagai wakil dari suatu makna atau penanda) bisa ditangkap oleh penafsir lainnya. Penafsir ini adalah unsur yang harus ada untuk mengaitkan tanda dengan objeknya.

Berdasarkan penjelasan di atas, bahasa tidak hanya berfungsi sebagai alat komunikasi, tetapi sangat berperan penting dan luas dalam budaya dan pola pikir penutur yang mampu membentuk persepsi penuturnya. Dengan demikian, penjelasan para ahli itulah yang menjadi landasan peneliti untuk mengkaji "Pola Pikir di Balik Ungkapan Metaforis Bahasa Melayu Ternate: Sebuah Kajian dari Perspektif Linguistik Antropologi."

\section{Metodologi Penelitian}

Metode yang dipakai dalam penelitian ini adalah metode penelitian deskriptif kualitatif dengan pendekatan linguistik antropologi yang salah satu hasilnya adalah data berupa ungkapan metaforis. Metodologi kualitatif merupakan prosedur yang menghasilkan data deskriptif berupa data tertulis atau lisan di masyarakat bahasa (Djajasudarman 1993:10). Untuk mendapatkan data penelitian dipergunakan penelitian lapangan (field research).

Dalam melakukan penelitian ini diutamakan latar alamiah (konteks) dari suatu keutuhan. Kebiasaan-kebiasaan atau perilaku masyarakat penutur BMT tidak dapat dipisahkan dari konteksnya. Perilaku itu hanya dapat dianalisis 
melalui keterlibatan langsung di lapangan, yakni suatu proses komunikasi. Metode deskriptif yang digunakan ditunjang oleh teknik ethnographic interview dari Spradley (1979). Tahap-tahap dan teknik penelitiannya dijabarkan sebagai berikut: metode pengumpulan data dalam bentuk wawancara etnografis, yaitu cara yang terbuka dan mendalam. Pada saat wawancara ini peneliti merekam dan mencatat data yang ditemukan dari narasumber. Untuk menyiapkan data yang akurat, penulis melaksanakan wawancara dengan berdasar pada suatu model wawancara etnografis dari Spradley (1979) dengan mengajukan pertanyaan deskriptif yang terdiri dari: 1) Grand Tour Question, yaitu tanyaan utama yang berkaitan dengan suatu objek pada suatu tempat secara menyeluruh dari yang umum sampai pada yang khusus. Wawancara dilakukan sambil mengamati proses kegiatan yang sedang berlangsung. Sebagai contoh, pertanyaan: "Dapatkah Anda berkomunikasi dalam BMT secara baik dan benar?” 2) Mini Tour Question, yaitu tanyaan yang lebih khusus atau mendalam, yaitu yang menyangkut pengalaman. Dalam hal ini pengalaman-pengalaman yang berhubungan dengan kegiatan komunikasi menggunakan BMT. Sebagai contoh, “Tolong Anda jelaskan waktu penggunaan ungkapan BMT, baik yang mengandung nilai positif maupun yang mengandung nilai negatif dalam berkomunikasi sehari-hari!" 3) Example Question, yaitu tanyaan yang lebih spesifik dengan cara mengambil suatu contoh peristiwa atau kegiatan/tindakan yang diketahui informan, kemudian informan diminta memberi contoh misalnya, "Bagaimana ungkapan metaforis BMT untuk seseorang atau nelayan yang akan mencari ikan?" 4) Experience Question, yaitu tanyaan yang menghendaki informasi budaya yang berupa pengalaman pribadi ataupun orang lain yang pernah dialami sendiri atau dilihat oleh informan, contoh: “Tolong ceritakan pada saya pengalaman Anda menggunakan ungkapan metaforis BMT yang berkaitan dengan etika, moral atau mentalitas kerja dipandang dari sisi positif dan negatif." 5) Native Language Question, yaitu tanyaan mengenai bahasa daerah yang digunakan informan dalam kehidupan sehari-hari, misalnya, "Apa sebutan 'apa yang dikatakan?' dalam BMT?” Selain pengumpulan data primer ada juga data sekunder, yakni data tertulis, seperti data yang terdapat dalam konteks lagu BMT, referensi ungkapan tradisional daerah Maluku, Televisi, dan lain-lain.

Teknik analisis data penelitian ini didasarkan pada teknik yang dikemukakan oleh Miles dan Huberman (1992). Teknik analisis yang dimaksud adalah (1) analisis dilakukan selama pengumpulan data dan (2) analisis dilakukan setelah data terkumpul. Analisis data pada saat pengumpulan data diperlukan agar secara kritis menyeleksi data-data ungkapan metaforis yang relevan dengan penelitian ini.

Analisis setelah pengumpulan data pada prinsipnya mengacu pada kerangka kerja penelitian kualitatif yang meliputi: pengumpulan data, mentranskripsi data, penyajian data, penarikan kesimpulan, dan hasil akhir dari pola pikir di balik ungkapan metaforis Bahasa Melayu Ternate yang ada di Desa Sea Tumpengan, Sea, Sea Mitra, dan Buha.

Pertama, data yang dikumpulkan dengan teknik observasi dan kajian pustaka ditata dalam bentuk transkripsi data. Kedua, data dianalisis dengan cara sebagaimana dikemukakan oleh Miles dan Huberman (1992) yang didasarkan pada prinsip berikut: pertama, analisis data dilakukan selama dan setelah pengumpulan data 
(dalam kondisi data peneliti bergantung pada hasil informasi yang diperoleh dari informan). Kedua, reduksi data, sajian data, dan penarikan simpulan merupakan hasil pencermatan dan pemahaman secara hermeneutis dari sumber data. Tahap reduksi data merupakan tahap yang meliputi pengidentifikasian. Tahap sajian data, meliputi kegiatan penataan data sesuai dengan jenis masalah yang diteliti, yaitu pola pikir di balik ungkapan metaforis bahasa Melayu Ternate di Desa Sea Tumpengan, Sea Mitra, dan Buha. Ketiga, analisis yang dikerjakan per sumber data. Masalah yang telah ditetapkan, yaitu apa saja ungkapan metaforis BMT, makna dari BMT, dan bagaimana ungkapan itu mencerminkan pola pikir penutur BMT. Keempat, jika analisis data dirasakan kurang memadai dan kurang mencukupi, maka dilaksanakan kembali pengumpulan data, reduksi data, dan sajian data. Demikian seterusnya sehingga dapat menghasilkan analisis yang utuh dan menyeluruh.

Makna ungkapan metaforis BMT diperoleh dengan penerapan teori semiotik de Saussure (1966) dan Peirce (2001) seperti yang dijelaskan dalam tinjauan teori.

\section{Pembahasan}

\section{Metafora, Makna Ungkapan, dan Pola Pikir}

Dalam subbab ini diuraikan hasil penelitian mengenai data-data ungkapan metaforis BMT tentang pola pikir masyarakat penutur BMT. Setelah melakukan penelitian, peneliti mendapatkan teks-teks hasil percakapan dari sumber-sumber, informan penutur BMT yang berada di Desa Sea Dua. Data yang ada dianalisis dan diseleksi karena tidak semua ungkapan BMT mengandung ungkapan metaforis. Data yang diambil hanyalah data ungkapan-ungkapan metaforis BMT yang memenuhi kriteria seperti yang dikemukakan oleh Wahab, baik data lisan maupun data tulis.

Ungkapan-ungkapan metaforis yang terkumpul diatur dan disusun sebagai berikut:

1. Diterjemahkan dalam bahasa Indonesia (BI).

2. Ditarik makna ungkapan sesungguhnya.

3. Diberi penjelasan untuk menentukan pola pikir di balik ungkapan metaforis BMT.

Ungkapan-ungkapan Metaforis Bahasa Melayu Ternate.

1. Ngana cuma baronda-baronda di jalang.

'Anda hanya ke sana-kemari di jalan.'

a. Baronda-baronda 'malam ini Bapak Boy yang bertugas baronda malam'

b. Baronda-baronda 'ke sana-kemari.'

c. Pola Pikir dari ungkapan barondabaronda adalah berputar-putar ke sanakemari, atau hanya jalan-jalan, tidak ingin mencari pekerjaan sehingga orang seperti inilah bisa dikategorikan sebagai orang malas yang tidak ingin berusaha. Ini juga merupakan suatu nasihat atau ajakan bagi siapa saja untuk mau bekerja keras demi masa depan karena bila kita mau bekerja keras yang akan menikmati hasilnya adalah kita juga yang telah berusaha sehingga mendapatkan hasil yang baik.

\section{Anak ini pe bantal setang skali.}

'Anak ini sangat suka tidur.'

a. Bantal 'Sarung bantal kepala saya akan dicuci.'

'Anak ini tidak dapat tidur tanpa bantal guling.'

'Bantal kursi ibu sangat indah.'

Setang 'Tadi malam saya melihat hantu.'

b. Bantal setang 'suka tidur' 
c. Pola pikir dari ungkapan ini adalah suatu teguran supaya jangan sering tidur di saat orang lain sibuk melaksanakan pekerjaan untuk kebutuhan hidup. Akibat dari kebanyakan tidur hidup bisa kekurangan. Bantal setang diibaratkan setan pada malam hari yang berkeliaran ke sanakemari dalam kegelapan dan pada siang hari dia tidur seharian. Orang yang tidur sudah pasti ditemani dengan bantalnya. Kebanyakan tidur dapat berakibat tidak baik bagi kesehatan.

\section{Tesa pe muka tra bae pa kita}

'Wajah Tesa tidak bagus terhadap saya.'

a. Tra 'kita tra ada uang' 'dia tra punya baju bagus' 'pemuda itu tra kerja'

Bae 'ibu ini bae hati' 'kesehatan anak ini bae-bae saja'

b. Tra bae 'tidak bagus'

c. Pola pikir dari ungkapan di atas adalah sesuatu yang diperlihatkan dengan wajah yang tidak baik tra bae. Ini diumpamakan sesuatu barang busuk, rusak, kedaluwarsa yang ditunjukkan kepada kita sehingga terlihat atau muncul reaksi wajah yang tidak bersahabat, muka marah. Tentu barang yang diperlihatkan itu tidak sesuai dengan keinginannya, atau bisa juga dengan perlakuan yang dilakukan tidak berkenan dengan hatinya. Mungkin saja telah membuat perasaannya kecewa, sakit akibat kata-kata yang keluar dari mulut lawan bicara, begitu mengecewakan atau sakit sehingga dari situlah diperlihatkan atau muncul muka yang tidak bagus (tra bae).

\section{Ngana duduk di muka cuma prong saja}

'Anda duduk di depan hanya hiasan saja.'

a. Prong 'prong bunga di atas meja' 'prong orang kawin'

'prong lukisan di pameran sangat menarik'

'prong pernak-pernik natal'

b. Prong 'hiasan'

c. Pola pikir dari ungkapan ini berupa teguran kepada orang malas yang hanya berdiri atau duduk dengan sikap yang bingung. Tidak tahu akan melakukan pekerjaan apa. Karena sikapnya yang malas untuk belajar sehingga dia hanya berdiri atau duduk diam. Atau pekerjaan itu bisa dilakukannya, tetapi karena dia malas untuk bekerja maka dia hanya mengambil sikap untuk berdiam diri. Hal ini sering berlaku bagi anak-anak muda yang malas sehingga ditegur oleh orang tua dengan menggunakan ungkapan seperti ini.

\section{Jantong talapas kita dengar kecelakaan ini.}

'Saya terkejut mendengar kecelakaan itu.'

a. Jantong 'jantong manusia' 'jantong hewan'

Talapas 'ayam talapas' 'sapi talapas'.

b. Jantong talapas 'terkejut'.

c. Pola pikir dari ungkapan ini berupa penyampaian akan isi hatinya yang terkejut saat mendapat kabar atau mendengar cerita sedih ataupun sebaliknya. Kaitan dengan ungkapan di atas merasa terkejut mendengar berita kecelakaan. Waktu seseorang mendengar berita ada kecelakaan, jantung terasa tidak berfungsi lagi, terdiam, terkejut, tak bisa melakukan apa-apa. 


\section{Sapa yang masak nasi ba hati.}

'Siapa yang masak nasi masih mentah?'

a. Ba hati 'ba hati orang'

'ba hati sapi'

'ba hati ayam'.

b. Ba hati'masih mentah'

c. Orangyangbelumterlalumahirmemasak nasi, suatu sindiran halus kepada orang lain bahwa apa yang dikerjakannnya itu hasilnya tidak baik. Jadi, masih harus belajar memasak. Ungkapan ini berupa teguran bagi orang yang bekerja kurang hati-hati akan menghasilkan pekerjaan yang tidak baik. Seperti halnya dengan pekerjaan memasak yang dilakukan karena tidak teliti sehingga hasilnya mengecewakan.

\section{Anak ini beking diri tua.}

'Anak ini sikapnya kelihatan tua.'

a. Beking 'bapak beking rumah kayu' 'ibu beking kue panada'

'kakak beking motor yang sudah

rusak'

Diri 'diri sendiri'

'dirinya'

'dirimu'

Tua 'orang tua'

'mangga tua'

'kelapa tua'

b. Beking diri tua 'kelihatan tua'

c. Pola Pikir kata-kata ini ditujukan kepada anak-anak yang sikap atau perilakunya seperti orang dewasa.

8. Jangan gonceng tiga orang di motor nanti tu ban manangis.

'Jangan membawa tiga orang di motor karena itu ban akan bocor.'

a. Ban 'ban mobil' 'ban motor'

'ban sepeda'

Manangis 'anak manangis'

'bayi managis'

'ibu manangis'

b. Manangis 'ban bocor'

c. Pola Pikir dari ungkapan ini berupa teguran atau peringatan supaya tidak melakukan sesuatu yang melebihi dari ketentuan yang ada supaya tidak terjadi sesuatu yang tidak diinginkan. Kata kerja menangis yang dalam keadaan sedih biasanya dilakukan oleh manusia. Menangis diterapkan kepada bendabenda dengan tujuan supaya ada rasa kasihan dan tidak melakukan sikap yang meremehkan terhadap benda tersebut.

9. Kita mo makang banyak mar malo hati pa tuang rumah.

'Kita mau makan banyak, tetapi malu kepada keluarga.'

a. Malu 'malu makan'

'malu terhadap guru

'anak malu-malu'

Hati 'hati babi'

'hati anjing'

b. Malo hati 'muncul perasaan malu'

Malo hati 'timbul rasa malu'

c. Pola Pikir ungkapan ini adalah suatu peringatan bagi seseorang yang melakukan sesuatu dan akibat dari perbuatan tersebut orang itu akan mendapat malu dari orang lain. Jadi, sebelum dia melakukan sesuatu dia sudah mengetahui akibatnya. Untuk itu, menjadi suatu pilihan baginya lebih baik dia tidak melakukannya. Namun, sebenarnya dia sudah tidak ingin melakukannya. 


\section{Ikan-ikan di laut Ternate so di kuli aer}

'Ikan-ikan di laut Ternate sudah berenang di atas air.'

a. Kuli 'kuli manusia' 'kuli binatang'

Aer 'aer tawar'

'aer asin'

'aer mendidi'

b. Kuli aer'permukaan air laut'

c. Pola pikir di balik ungkapan ini adalah sebagai contoh sesuatu binatang yang berada pada kulit manusia. Hal ini diibaratkan ikan yang sudah berenang di atas air laut sehingga dikatakan kuli aer atau lapisan akhir dari laut. Sebagaimana tubuh manusia yang terdiri dari beberapa lapisan, ada daging, lemak (BMM tawa), kulit, dan lain-lain. Begitu juga laut berlapis-lapis, yakni dasar laut, atas air laut yang diistilah penutur Bahasa Melayu Ternate dengan kuli aer. Kulit selalu berada pada bagian luar dari suatu benda atau makhluk. Umumnya, kata ini (kuli aer) ditujukan kepada nelayan agar dapat melaksanakan pekerjaannya dengan cepat karena ikan-ikan secara tiba-tiba sudah menampakkan tubuhnya di atas air laut dan terlihat oleh mata manusia. Penampakan ikan-ikan ini tidak sering terjadi sehingga bila hal ini terjadi merupakan berkat besar bagi kaum nelayan. Hal ini merupakan peringatan bagi nelayan untuk tetap jeli memperhatikan lingkungan tempat kerja.

\section{Klasifikasi Ungkapan Metafora}

Ungkapan-ungkapan metaforis yang terkumpul diatur dalam klasifikasi, seperti yang dikemukakan oleh Wahab (1986) sebagai berikut.

1. Metafora Nominatif Subjektif.

2. Metafora Nominatif Objektif/

Komplemen (pelengkap).

3. Metafora Predikatif (Verba).

4. Metafora Kalimat.

Berdasarkan data ungkapan bahasa Melayu Ternate yang dikumpulkan, terdapat ungkapan-ungkapan metaforis yang ada yang sesuai dengan keempat jenis metafora yang diperkenalkan oleh Wahab (1986), yaitu:

1. Ungkapan Metafora Nominatif Subjektif

Ungkapan metafora nominatif subjektif dalam BMT, seperti:

1) Orang punya yang boleh skolah situ. 'Hanya orang kaya yang boleh bersekolah di situ.'

2). Panyaki malendong pa ngoni.

'Akan mendapat banyak penyakit kamu.'

3) Jantong ta lapas kita dengar kecelakaan itu.

'Terkejut saat kita mendengar kecelakaan itu.'

2. Ungkapan Metafora Nominatif Objektif/Pelengkap (komplemen)

Ungkapan metafora nominatif objektif/ pelengkap (komplemen) dalam bahasa BMT, seperti:

1) Hana pe kuli so Glap.

'Kulit Hana sudah kelihatan hitam.'

2) Ngana duduk di muka hanya prong. 'Anda duduk di depan hanya menjadi hiasan saja.'

3) Luky ini so boleh kaweng spaya todoh. 3. Ungkapan Metafora Predikatif (verba) 
Ungkapan metafora predikatif (verba) dalam BMT, seperti:

\section{Josua pe badan pica.}

'Josua sudah sangat gemuk.'

1) Ngana ini pe bantal setang skali.

'Anda ini selalu tidur.'

2) Ta pe cinta maraya pa ngana.

'Saya mencintaimu begitu luar biasa.'

4. Ungkapan Metafora Kalimat

Ungkapan metafora kalimat dalam BMT, seperti:

\section{1) Panta leher so tere.}

'Leher sudah sangat tegang.'

\section{2) Manganto babi nae.}

'Rasa mengantuk tiba-tiba datang.'

\section{3) Cinta masih babasah.}

'Hubungan cinta yang masih intim.'

\section{Simpulan}

Setelah melalui penelitian dan pembahasan masalah yang telah diuraikan pada bab-bab sebelumnya, dapat disimpulkan sebagai berikut:

1. Dalam berkomunikasi seharihari subetnis Ternate yang sudah menetap di Desa Sea Tumpengan, Sea Mitra, dan Buha, serta di Kota Manado, mereka sering menggunakan ungkapan-ungkapan metaforis. Ungkapan-ungkapan metaforis ini merupakan bagian dari cara berkomunikasi. Ungkapan ini bukan hanya ditujukan kepada penutur BMT, tetapi dikomunikasikan juga kepada masyarakat yang bukan etnis Ternate yang ada di sekitar mereka.

2. Ungkapan-ungkapan metaforis BMT menggambarkan bagaimana pola pikir masyarakat penutur BMT berperilaku positif dan negatif terhadap apa yang ingin disampaikan. Pola pikir di balik ungkapan metaforis BMT muncul setelah dikaitkan dengan pengamatan alam sekitarnya. Ungkapan-ungkapan metaforis merupakan respon terhadap budaya lingkungan, terutama yang berhubungan dengan perilaku dan tindakan sehari-hari yang berkonotasi positif dan negatif.

3. Dari keseluruhan ungkapan-ungkapan metaforis BMT tersebut, tersirat makna budaya yang mengandung nilai-nilai kehidupan atau gambaran perilaku dan cara hidup dalam masyarakat. Pola pikir yang ada memiliki nilai kehidupan yang berupa nasihat-nasihat, sopan-santun, pergaulan, kerajinan, teguran, peduli kesehatan, sikap bijaksana, dan lainlain.

\section{Daftar Pustaka}

Abdurachman. 1973. Bunga Rampai Sejarah Maluku (1). Jakarta: Lembaga Penelitian Sejarah Maluku.

Apituley. 1983. Sejarah dan Perkembangan Melayu Ternate. Jakarta: Departemen Pendidikan dan kebudayaan.

Campen, CFH. 1885. "Ternataansche Pantoen's." TBG 30; 443-450, 625-631.

Casson. 1981. Language Culture and Cognition. Antropological Perspektive. New York: Macmillan Publishing.

Djajasudarma, F. 1993. Metode Linguistik: Rancangan Metode Penelitian dan Kajian. Bandung: Fefika Aditama.

Dyen, I. 1984. (dalam Gorys Keraf). Linguistik Bandingan Historis. Jakarta: Gramedia.

Folley, W. 1997. Antropologycal Linguistics: 
University of Sydney: Blackwell Publischers.

Grimes, 1984. "Bahasa-Bahasa Daerah Maluku Utara dan Halmahera Tengah.” Ambon, Makalah pada Seminar Penelitian Maluku dan Irian Jaya, 23-28 Januari 1984.

Hueting, A. 1907. "Lets over de 'Ternataansch -Halmaherasche' taal groep." BKI

60 hal. 369-411.

Hymes, D.H, 1974. "The Ethnograpy of Speaking." In. T. Gladwin and W.C. Sturtevant. (eds.). Antropology and Human Behavior. Washington: Antropologycal Society of Washington.

Jakobson. 1979. Teori Sastra Masa Kini. Jakarta: Penerbit P.T Gramedia.

Knights. L.C dan Cottel. 1960. Metaphorand Symbol.London: Butterwoth Scietific Publication.

Koentjaraningrat, 1985. Pengantar Ilmu Antropologi. Jakarta: Aksara Baru.

Levin, R. 1997. Semantics of Metaphor. Baltomore: The Jhon Hopkins University.

Longman. 2005. Active Students Dictionary (Compac Disk). New York: Windows Corp.

Mahyuni, 2004. "Inderectness pada Masyarakat Sasak: Fenomena Metafor." Dalam Linguistik Indonesia, Februari 2004. Jakarta: Yayasan Obor Indonesia.

Masinambow, E.K.A. 1998. "Hubungan Timbal Balik antara Bahasa dan Budaya." Materi Kuliah. Jogjakarta: Universitas Gadjah Mada.

Marvin, H (dalam Spradley, 1979). The Ethnographic Interview. New York: Holt and Winston.

Miles and Huberman. 1992. Analisis Data Kualitatif. Terjemahan Tetap Rohandi. 1992. Jakarta: UI Press.

Muhamad, 2007. "Makna Budaya Ungkapan dalam Tarian Tradisional Togal di Makian Pulau Kabupaten Halmahera Selatan."
Nendissa, M. 1991. Ungkapan Tradisional Daerah Maluku. Ambon: Departemen Pendidikan dan Kebudayaan.

Ortony (ed.). 1979. Metaphor and Thought. Cambridge: Cambridge University Press.

Peirce (dalam Sobur). 2006. Semiotika Komunikasi. Bandung: Penerbit PT Remaja Rosdakarya.

Sangaji. 1991. Kata Sapaan dan sistemnya dalam Bahasa Makian di Maluku Utara. Manado: Fakultas Sastra Universitas Samratulangi Manado.

Saussure, P. De. (dalam Sobur). 1966. Course in General Linguistics. New York: Mc GrawHill Company.

Siregar. 2004. "Metafora Kekuasaan dan Metafora Melalui Kekuasaan." Dalam Purwo, K.B. (ed.) PELBA 17. Jakarta: Unika Atmajaya dan Yayasan Obor Indonesia.

Spradley, P.J. 1979. The Ethnographic Interview. New York: Holt Rinehart and Winston.

Sudaryanto. 1993. Aneka dan Teknik Penelitian Bahasa. Jogjakarta: Gadjah Mada University Press.

Syapora, Y. 2008. "Perjalanan Penelitian Profil Bahasa di Kayoa Malluku-Utara."

Turner, Victor. 1986. Dramas Fields and Metaphor. Ithaca: Cornel University Press.

Wahab. 1986. "Javanese Metaphor in Discourse Analysis." (Unpublished Disertation, University of Illinois at Campaign-Urbana).

------, 1988. "Pendekatan Psikolinguistik terhadap Metafora dan Implikasinya dan Pengajaran Sastra" (makalah di Sajikan pada seminar Bahasa dan Sastra Indonesia serta Pengajarannya, Bulan Bahasa di IKIP Malang, 8 Oktober 1988).

Wheelright. 1964. Metaphors and Reality. Bloomington: Indiana University Press. 